\title{
Parenting of Children with a High Risk Birth in Mexico: Psychometric Validation of a Parental Emotional Scale
}

\section{Conde-Reyes María de la Paz ${ }^{1 *}$, Jiménez-Quiroz Rosalía ${ }^{1}$, Padilla Gámez Nélida ${ }^{2}$, Romero-Palencia Angélica ${ }^{3}$, López Becerra Claudia ${ }^{4}$, Guido Campuzano Martina Angélica ${ }^{1}$ and Castro Soto Reyes Laura Mercedes $^{5}$}

${ }^{1}$ National Institute of Perinatology, Department of Pediatric Follow-up, INPER, Mexico

${ }^{2}$ Faculty of University Studies of Iztacala, UNAM, Doctorate in Family Studies, CENCALLI Institute, Mexico

${ }^{3}$ La Salle University in Pachuca, Faculty of Human Sciences, Doctorate in Family Studies, CENCALLI Institute, Mexico

${ }^{4}$ National Pedagogic University, Doctorate in Family Studies, CENCALLI Institute, Mexico

${ }^{5}$ Ministry of Health, Mexico

*Corresponding Author: Conde-Reyes María de la Paz, National Institute of Perinatology, Department of Pediatric Follow-up, INPER, Mexico.
Received: June 02, 2021

Published: June 25, 2021

(C) All rights are reserved by Conde-Reyes

María de la Paz., et al.

\begin{abstract}
Introduction: A high risk birth implies more responsibilities for parents, who suffer negative effects in their global quality of life in a direct and indirect form, presenting disorders of the emotional sphere, amongst others. Perceiving their child as vulnerable, weak and sickly generates emotional sequelae in the parents that affect the child's development.

Emotions are fundamental aspects of human relationships and are invariably involved in parenting as the first emotional links between parents and children are established. Parenting involves emotions related to the difficult task adults face since the beginning of their child's life due to birth conditions. This may result in short and long-term altered emotional states that influence attitudes towards parenting and impact the high risk newborn's development.

In Mexico, little has been inquired about parent emotions concerning parenting in this population.

Objective: This study has the objective of validating an emotional scale in parents concerning parenting of high risk newborns.

Materials and Methods: Non-experimental, exploratory, cross-sectional study with intentional non-probabilistic sampling of an only sample. 710 parents of children with a high risk birth who attended the pediatric follow-up at the National Institute of Perinatology (INper) participated. 73.2\% (520) were women and 26.8\% (190) men, with $\mu=35.5$ years (S.D.= 8.15) of age.

Results: An exploratory factor analysis (EFA) was conducted using the method of main components with orthogonal rotation. The analysis yielded a Kaiser-Meyer-Olkin index that revealed a factorizable matrix (KMO $=0.829$ ), as well as a significant Bartlett's test of sphericity $(\mathrm{p}<.000)$, which allowed for an adequate factor analysis. The instrument included 14 items distributed in three factors: Guilt and fear, Joy and Happiness and States associated with negative emotions towards parenting that account for $54.16 \%$ of total variance, with a global Cronbach alpha of 0.81 .

Conclusion: The present work emphasizes the relevance of having a scale that enables learning about emotions that parents experience when parenting a high risk child. It is concluded that the instrument is valid and reliable for the Mexican population. It is suggested to use it in clinical practice and in future studies side by side with other scales that contain variables or constructs related to parental emotions in their factorial structure.
\end{abstract}

Keywords: Parental Emotions; Parenting; High Risk Birth; Validation 


\section{Introduction}

Pediatric diseases are a health threat to developmental processes in children [1]. Specifically, some neonatal complications that may present at birth, including hyperbilirubinemia, sepsis, respiratory distress and neurological complications are considered a risk, and may affect neurological and behavioral development. Likewise, prematurity, meaning low weight for gestational age, less than $1500 \mathrm{~g}$ and a gestational age less than 32 weeks, is one of the main risk factors in newborns and a significant perinatal health problem $[2,3]$.

Prematurity involves a high risk birth, and this type of birth encompasses diseases, chronic disabilities, consequences in development and as a result, poor quality of life for the newborn [4]. In Mexico premature birth is the main cause of death amongst newborns during the first four weeks of life and the second cause of death amongst children under five years of age, after pneumonia [5].

Health hazards in minors with a high risk birth imply a greater responsibility for the family and the parents, who suffer negative effects in their global quality of life in a direct and indirect form, presenting a greater amount of disorders of the emotional sphere [6]. Although factors that harm children's development are multidimensional, different areas of development of the patient and family are impacted by a high risk birth: physical, emotional, social and occupational, causing an increase in stress and anxiety in parents and the family [7].

Thinking of their child as weak, vulnerable or sickly generates emotional sequelae in the parents and affects the child's development, giving reason to analyze biopsychosocial problems [8]. Results of investigations in neurodevelopment of these children agree that biological risk factors (prenatal, perinatal and postnatal) pose a risk for their physical and cognitive development $[2,9]$.

As a result, prematurity involves difficulties and disorders in development of these children, specifically regarding cognitive development and its manifestation measured through an intellectual quotient (IQ). Extreme preterm and very low birth weight newborns have a higher risk of presenting cognitive disorders or poor intellectual performance $[9,10]$.

Nevertheless, it is considered that in cognitive development of a child with a high risk birth, biological and socio-environmental factors interact such that family environment and parenting are rel- evant as an environmental risk factor for cognitive development in preterms ${ }^{9}$, and cognitive aspects have also been associated to emotional states [11-14]. This means that social health determinants may be protective or risk factors for cognitive abilities of children and influence a low IQ in children with a high risk birth $[11,15]$. Global intelligence in children with a history of prematurity ranks in the average group mean $[9,16]$.

Likewise, parents of high risk children undergo high stress levels and experience negative emotions, which can result in altered emotional states in the short and long term and thus have a negative emotional impact on family life $[3,17]$. This occurs especially when there is a prolonged hospital stay or after discharge, in contrast with the presence of positive emotions when transition to the home occurs promptly. Therefore, concern and complex emotions of parents are governed by trust, hope and joy felt in relation to the time in which discharge home occurs. Nevertheless, regarding the child's care, fear or anxiety are still present due to long term uncertainty of prematurity [18].

Therefore the parent's experience when facing a high risk birth is usually "disconcerting" given that from the start they express emotions regarding the difficult experience [19]. In light of an unhealthy child, ambivalent emotions are reported: love, fear, concern, rejection, guilt. Acceptance of the child and the health situation depends on each of the parent's personal situation and degree significance to them [20].

Emotional implications derived from stress, anxiety, fear, frustration and family rearrangement when facing a high risk birth are complex. Sometimes negative emotions persist for several years and go through different phases before reaching acceptance: denial, anger, resentment, guilt, self-reproach, sadness and depression, each of these impacting the interaction with the child and the way in which the child is taken care of and educated [13]. For this reason, children with a high risk birth and their families must ideally be incorporated into a pediatric follow-up program in order to monitor adequate global development and identify the most frequent problems that occur. At the same time, the parents must adapt to their child's health conditions without this becoming a crisis that influences family dynamics and brings permanent negative feelings to the parents $[13,21]$.

Analyzing the consequences in family life, specifically the differences between psychological functioning and overload in parents who care for sick children when compared with parents with 
healthy children, in the first group there were higher levels of anxiety and depression. This concludes that a burden is generated, altering quality of life in these families [22].

After hospital discharge, parents will need to continue resolving health conditions derived from their child's high risk birth, as well as common situations in family life, thus modifying family schemes and dynamics. Parents are not prepared for this experience and therefore will find it difficult and be marked emotionally through time in spite of a favorable progress in the minor [8,13]. Thus the emotional states through which parents go through require an intense work of psychic elaboration, emotional regulation and cognitive resignation that continue long after hospital discharge and influence attitudes towards parenting $[3,23]$.

As a result of the emotional impact parents face in light of a high risk birth, as well as the possible consequences on neurodevelopment of their children, in these families parenting tends to be vague; norms are not established, many times due to fear of demanding too much from children [9]. In a similar manner, this may lead parents to maintain parenting behaviors influenced or determined by factors related explicitly with the child's high risk birth [23-25]. For example, through non-exigency or flexibility in norms and overprotection of children in the future $[8,19,26]$.

The systemic approach acknowledges that family develops through different stages. In some stages there may be stagnation, typical of the family cycle, requiring a transformation or development; if left unresolved, there may be family dysfunction with an altered parental role and therefore, altered parenting [27,28].

On this same line of research, a review of the literature that delved into mental health of the parents and included emotional states as a factor that affects emotional and social development of children, concluded that stress and depression affect parenting in a negative way [29]. In a longitudinal study seeking predictors that affect parenting, the results indicate a mother's negative perception of her child, low parental satisfaction and a history of punitive discipline, are risk factors for high levels of abuse and emotional disorders in the mother [30]. Similarly, in a work concerning risk factors that increase risk for the mother's mental health and influence the children's development, the group of investigators concluded that stress, depression and anxiety are associated with socioeconomic problems, family conflicts and the lack of support networks, which affects parenting [31]. It is worth noting that very few studies have focused on knowing the effects or emotional sequelae of the parents in the time following hospital discharge of their children [18].
While parenting is determined by family characteristics and the interactive bonds within the family, it is important to analyze not just the parent's expertise, attitudes and practices, but also other characteristics such as: emotions or attachments. This reaffirms that parenting begins with the establishment of emotional ties [26].

Parenting involves multidimensional aspects that may be stressing when facing responsibilities, thus emotions are implied [32]. Caring relationships amongst members occur through the manifestation of emotions and feelings among them [28].

The emotional component of parenting is classified into three parental styles of education for children; two determining elements are mentioned which characterize parenting styles: the percentage of affection parents show when interacting with their children and the percentage of control the parents show towards their child's behavior [33]. Based on literature reviews, the emotional phenomenon may be explored under the model of positive emotions by Frederickson [34,35] and negative emotions by Lazarus and Lazarus [36].

Every emotion is useful and has important functions in social and personal adaptation, even the most unpleasant ones [36]. For example, in guilt the individual feels responsible for another's suffering; additionally, there is fear towards loss of love of close ones, or feeling responsible for damages caused to a loved one, thus creating a need to repair the damage due to a feeling of acting inappropriately with the other [37]. Regarding fear, it is known to promote protection through escape responses and avoidance of a dangerous situation, as well as directing attention towards the feared stimulus, besides mobilizing a great amount of energy to execute responses in a more precise form [38,39]. Joy and happiness are regarded as a positive pleasurable, strengthening experience, coupled with feelings of delight, comfort and wellbeing that provide the necessary energy to carry out behaviors [39].

Attempts have been made to measure some factors related to the complex construct of emotions and parenting. One of the existing complications to do so is the possibility to have valid and reliable instruments adapted to Mexican population. It is worthy to mention that in the study of parenting, instruments that measure styles or practices predominate; little has been studied about parental emotions towards parenting. Besides, existing instruments have focused on populations of parents with healthy children and little is known about those with children with a high-risk birth. 
Some examples of analyzed instruments are the Scale of Affective Profile by Del Campo, Cortés, Herrera and De la Peña (1996) [40], which assesses the way in which a person feels regarding an object at a given time. It comprises 83 adjectives, involving six factors that accounted for $57.8 \%$ of the total variance: depressive mood, discomfort, fatigue or tiredness, anger, lack of concentration and tension or anxiety. Reliability indexes obtained for the factors were $\alpha=0.89$ y $\alpha=0.85$. In Latin America the Perinatal Psychologic Interview by Oiberman, Santos and Nieri has been developed (2010) [41]. This instrument favors the expression of emotions and problems immediately after birth, gathers events through meaning and re-signifying on behalf of the mother: planning, acceptance, reject of the pregnancy, imaginary child or expectations, dreams, emotional responses towards ultrasounds, impact towards the preterm birth, reactions towards the real child that determine difficulties in breastfeeding and the strangeness towards the newborn. Levels of reliability or validation were not reported. On the other hand, the Scale of Parental Emotional Relation by López-Alpinez (2014) [42], including 30 items with $\alpha=.730$, helps detect the perception of the parents concerning their familial relationship with their children. The dimensions it includes are: noticing, intonation, sharing internal and external worlds, sovereignty, repair and investment; this last one includes: listening, responding, recognizing needs and sacrificing.

Of the instruments or scales published in Mexico, there is none that exclusively measures parental emotions towards parenting, so it was necessary to look for one that measures the emotional component in its factors or subscales, finding this in the Scale of Perception of Parenting created by García-Méndez, Rivera-Aragón and Reyes-Lagunes (2014) [43]. The factor called negative emotional perception refers to the mood of mothers and fathers, associated to behavior they consider inadequate in their child. This factor covers the perception of discomfort, frustration, sadness, disillusion and anger.

Given the relevance and appropriateness of the subject, the present work elicits the need to further examine the knowledge of other components of the experience of parents when trying to fulfill parenting. This includes emotions, which in spite of being less investigated, also form part of the construct of parenting, and also have implications in the child's development, such that the present work has the objective of validating a scale of parental emotions towards parenting a child with high risk birth.

\section{Methods}

The categories of analysis on which the wording and development of the present study are based were obtained from a previous exploratory study with focus groups. The focus groups revolved around a theme guide reported in literature about some topics that propose theoretical frameworks that antecede emotions.

After words, answers from the focus groups were transcribed, and an analysis based on content and frequencies was carried out with the help of the Atlas. Ti V5 software. Professional investigation experts participated as judges in the evaluation of items of the resulting questionnaire. From the results of this quantitative analysis done by the judges, there was an item cleanup, eliminating those with poor wording or those addressing sensitive subjects and confronting parent experience. Thus the validation of the contents was obtained through approval and validation by the judges $[44,45]$.

The resulting items were given the psychometric treatment described by Reyes Lagunes and García and Barragán (2008) [46]: 1. Item discrimination according to the method. 2. Exploratory factor analysis. 3. Obtainment of the internal consistency index.

Due to the specificity of the sample, pilot testing was performed in parallel with the validation of the instrument.

\section{Participants}

The sample included 710 fathers/mothers of children with high risk birth that attended the Department of Pediatric Follow-up of the National Institute of Perinatology (INPer) during the period between June 2017 and December 2018; 73.2\% (520) women and $26.8 \%$ (190) men, recruited by intentional non probabilistic sampling. The age ranges from 15 to 64 years, with $\mu=35.5$ (S.D.= 8.15). The majority of the sample has high school (29.7\%) or bachelor (22.7\%) studies. As to occupation, $45.51 \%$ stay at home, while $51.29 \%$ are economically active fathers and mothers. $49.7 \%$ were married, while $33.8 \%$ were unmarried.

\section{Procedure}

Fathers and mothers who attended pediatric follow-up at INPer were invited to answer the instrument voluntarily; they were explained the importance and objective of the investigation. Ethical principles of investigation with humans contemplated in the General Health Law and the Code of Ethics of Psychology were followed. The average time to complete the instrument was $10 \mathrm{~min}$ utes.

\section{Instrument}

Based on the item bank obtained from the exploratory study, a questionnaire was designed; it included 21 items, with a Likert 
type response scale of 5 points in terms of frequency (never, almost never, sometimes, frequently, always.

\section{Results}

After the application of the questionnaire, the data entry and psychometric analysis of the scale were performed. The statistical software SPSS from IBM was used for the statistical processing of data. The procedure of psychometric analysis, ${ }^{46}$ which consisted of carrying out an analysis of frequencies and bias from the highest item to 0.5 was performed, in order to understand the distribution of the answer choices, normal o biased. This was followed by a significant discrimination between the lower extreme and the higher extreme of the item groups, obtained through a Student $t$ test for independent samples with the purpose of detecting differences between groups. Finally, an item discrimination was made through the correlation of each item with the total scale in order to identify the level of association between items. In this phase no item was eliminated, since all the required criteria were met.

Subsequently, in order to determine construct validity an exploratory factor analysis was carried out using the Varimax main component method with orthogonal rotation, with the purpose of determining how many factors the items were grouped in. The Kaiser-Meyer-Olkin (KMO) test revealed a factorizable matrix (KMO = 0.829), and Bartlett's test of sphericity 2685.56 was significant ( $p$ $<0.000$ ), allowing the factor analysis to be carried out adequately. The items obtained clusters above 0.40 , indicating they measure the same construct. The EFA showed 3 factors that account for $54.16 \%$ of the total variance; once these factors were obtained, the items with a weight factor greater than or equal to 0.40 were chosen. The best version of the final instrument included 14 items, with a global Cronbach alpha of 0.81 , oscillating between 0.71 and 0.78 per factor. Table 1 shows the final factorial structure of the instrument.

\begin{tabular}{|c|c|c|c|}
\hline \multirow{2}{*}{ Items } & \multicolumn{3}{|c|}{ Component } \\
\hline & 1 & 2 & 3 \\
\hline I am fearful of raising my child in spite of having the support of my family. & .76 & .06 & .08 \\
\hline I feel overwhelmed in parenting my child. & .73 & .09 & .21 \\
\hline I feel guilt when I see my child and I have a hard time parenting now. & .70 & .13 & .16 \\
\hline I disapprove my way of raising my child. & .65 & .12 & .16 \\
\hline $\begin{array}{l}\text { Family makes me feel guilty when I want to correct my child, because they say: "Don't you } \\
\text { remember all that he/she suffered and look at you scolding him!" }\end{array}$ & .56 & -.01 & .18 \\
\hline I enjoy going out with my child. & .05 & .75 & .11 \\
\hline I enjoy activities with my child. & .15 & .74 & .19 \\
\hline I feel happy when I see achievements in my child. & -.02 & .73 & -.02 \\
\hline I enjoy the time I spend with my child. & .04 & .70 & .04 \\
\hline I feel satisfied and proud of the choices I have made while parenting my child. & .30 & .49 & .10 \\
\hline I lose control when my child does no to obey and I scream at them. & .18 & .05 & .78 \\
\hline When my child drives me crazy, I threaten him/her to obey. & .11 & .06 & .74 \\
\hline I easily lose control with my child because he/she disobeys me. & .19 & .12 & .73 \\
\hline I feel so stressed that I have very little tolerance with my child. & .35 & .15 & .68 \\
\hline Number of items & 5 & 5 & 4 \\
\hline Explained variance \% & 30.78 & 14.14 & 9.23 \\
\hline Self value & 4.31 & 1.98 & 1.92 \\
\hline Cronbach Alpha & .74 & .71 & .78 \\
\hline Mean (SD) & $\begin{array}{l}4.02 \\
(.79) \\
\end{array}$ & $\begin{array}{l}4.69 \\
(.44) \\
\end{array}$ & $\begin{array}{r}3.68 \\
(.79) \\
\end{array}$ \\
\hline KMO & 0.829 & & \\
\hline \multicolumn{4}{|l|}{ Bartlett's test of sphericity:: $X^{2}(.861)=2685.56 \mathrm{p}<.000$} \\
\hline $\begin{array}{l}\text { Component 1: Guilt and fear towards parenting, Component } 2 \text { Joy and happiness towards } \\
\text { associated with negative emotions towards parenting. }\end{array}$ & g, Com & ent 3. & \\
\hline
\end{tabular}

Tabla 1: Factorial structure of the Scale of Parental Emotions towards parenting of children with a high risk birth. 
The factors associated to parental emotions towards parenting a child with a high risk birth were defined in the following way:

- Factor 1: Guilt and fear towards parenting (5 items) that account for $30.78 \%$ of variance, obtaining a Cronbach Alpha's reliability score of 0.74 . This refers to the states of discomfort originated by fear, guilt or dissatisfaction towards parenting.

- Factor 2: Joy and happiness towards parenting (5 items) that account for $14.14 \%$ of variance, with a Cronbach Alpha of 0.71. This factor describes emotional states in which pleasure, enjoyment and wellbeing predominate towards parenting.

- Factor 3: States associated with negative emotions towards parenting (4 items) that account for $9.23 \%$ of total variance with a global Cronbach Alpha of 0.78. It refers to emotional states that create impatience, intolerance and despair, altering the process of parenting children with a high risk birth.

Based on the above, it can be observed that the scale of parental emotions towards parenting a child with high risk birth shows adequate levels of reliability, demonstrating it is an instrument applicable to Mexican population with such characteristics.

\section{Discussion}

The validation of the instrument of parental emotions towards parenting children with a high risk birth was carried out in Mexican population. 21 items were created based on the 24 original categories obtained from the content analysis of focal groups $[44,45]$.

On the basis of the exploratory factor analysis, the final scale included 14 items distributed in three factors: 1) Guilt and fear towards parenting, 2) Joy and happiness towards parenting, and 3) States associated with negative emotions towards parenting.

The resulting factors match those obtained with the instrument by García-Méndez, Rivera-Aragón and Reyes-Lagunes (2014) [46], who reported the category of emotional factors in parenting, naming it perception of parents about their child's parenting. This instrument reports the existence of a factor in parenting known as emotionally negative that refers to the parent's mood in light of behavior they consider inadequate on their child's behalf. This perception upsets, frustrates, saddens, disappoints and angers them. This matches factor 3 of the present scale.

Emotions play an important role modulating the individual's relation to his/her world [35]. In the family environment, caring relationships develop amongst members through manifestation of emotions and feelings amongst them [28]. Since their child's birth, parents of high risk children experience high levels of stress, anxiety and negative emotions, which can lead to altered emotional states in the short and long run [17]. Emotions are aspects implicated in parenting, given it involves multidimensional aspects that may be stressful when facing responsibilities of parenting [32]. This is reflected by the factors of the present scale.

In spite of the many existing instruments, in an extensive review of the literature no other instrument measuring parental emotions was found, neither one designed for parents of children with a high risk birth. It is important to highlight the relevance of each of the factors of the present scale and their theoretical background.

Factor 1 of the scale called guilt and fear towards parenting includes items that describe negative emotions of guilt, fear and dissatisfaction towards parenting of children with a high risk birth.

Parents claim responsibility and at the same time fear provoking more damage or suffering to their children through parenting practices, which probably creates in them a sense of guilt when cognitive, affective or behavioral assessments turn out different than expected. This could explain the parent's need to fix the alleged harm through a relaxed parenting or discipline [13,37]. On the other hand, fear implied in parenting is possibly related to the relative biological vulnerability with which parents continue to perceive their children following the high risk. From the systemic point of view, the above suggests the possibility that these parents are caught up in the birth stage of the family life cycle. In spite of requiring a transformation or advance along the cycle, the stagnation of these parents may lead to family dysfunction, basically related to an altered parental role and therefore, an altered parenting of the child $[13,27,28]$.

In factor 2 called joy and happiness towards parenting, specific items reflect positive emotions towards parenting of these children. According to Frederickson's theory, the emotion of joy(happiness) gives individuals the opportunity to enjoy current circumstances and integrate them into new visions of the world [35]. Due to health complications these parents must face during pregnancy, their child could be perceived as a valuable "product" stemming from the achievement of overcoming such complications, mirrored in their birth and physical wellbeing. Such that they joy and happiness they live through may be a positive experience, pleasurable and reinforcing, offering the energy needed to carry out appropriate behaviors in parenting according to the stage of the family cycle in which the family is found $[28,40]$.

In the items in factor 3 , called states associated with negative emotions towards parenting, the impatience, intolerance and de- 
spair parents experience while parenting may be observed. Unpleasant emotions such as impatience, intolerance and despair may be associated with demands and excessive requirements experienced in parenting, caused by tension generated in parents due to the biological risk of their children since birth. ${ }^{47}$ The interactions between parents and children are determined as much by external and internal motivations of the parents as well as characteristics of the child. In other words, characteristics of adaptability, demands and mood of the high risk child are added to characteristics such as health, acceptance of the child or displeasure of his/her parents towards the responsibilities of parenting $[32,48]$.

The preceding analysis emphasizes the importance of parents of these children having the support of health professionals belonging to pediatric follow-up programs, so that they can previously cope with this difficult experience and their parental functions, resulting in an emotional link with their high risk child that is free from emotional aftermath. Therefore, the use of this instrument is suggested in clinical practice to obtain a diagnosis that allows emotions experienced by parents to be treated on a primary and secondary level, having a positive impact on parenting of children with a high birth risk. In the same way, the future application of this instrument is recommended to know the implications of parental emotions on neurodevelopment of these children.

For further studies, it is suggested to explore validity of construct through the application in parallel of other scales that measure or contain in their factorial structure theoretical valuables or constructs related to other parental emotions. It is important to mention that given the non-probabilistic sample used, the results of this validation only apply to similar samples, this being the first version of the scale and a limit to this investigation.

\section{Conclusion}

The present study points out the relevance of having a scale that explores parental emotions towards parenting a high risk child. The results indicate that the scale has adequate levels of validity of construct and reliability. Therefore, the objective of the investigation, validating a scale including elements implied in parental emotions in parenting high risk children is fulfilled.

\section{Bibliography}

1. Hoehn J., et al. "The Role of Parenrs in promoting Children's Adjusrmenro Chronic Illness". En DeMichelis C., and Ferrari, m. (ed.). Child and Adolescent Resiliencie Within Medical Conrex Switzarland: Springer Internacional Publishing (2016): 51-62.
2. Confederación Nacional de Pediatría de México. "Manual neu $\neg$ rodesarrollo y estimulación temprana en pediatría" (2014).

3. Villamizar B., et al. "Madres descubriendo el amor incondicional en el proceso adaptativo de Hospitalización de su bebé prematuro". Revista Cuidarte 5.2 (2014): 782-791.

4. Romero S., et al. "Morbilidad del recién nacido prematuro tar $\neg$ dío durante su primer mes de vida comparado con el recién nacido de término". Perinatología y Reproducción Humana 27.3 (2013): 161-165.

5. Organización Mundial de la Salud [OMS] “Estadísticas Sanitarias Mundiales 2013”. Una Mina de Información sobre Salud Pública Mundial (2013).

6. Pretel EG. "Calidad de vida de tutores de niños del programa de asma bronquial del hospital Naylamp durante el año 2012". Tesis. Universidad Católica Santo Toribio de Mongrovejo, Perú, Chiclayo (2014).

7. Gómez MC. "Guía para padres de bebés nacidos prematuros. La Internación”. Revista Interdisciplinaria 32.2 (2015): 347366.

8. Gómez EC., et al. "Dificultades biosociales de la gran prematuridad”. Sociedad Española de Neonatología (2012).

9. Torres-González C., et al. "Inteligencia general en niños nacidos prematuramente". Cuadernos de Neuropsicología Panamerican Journal of Neuropsychology 10.2 (2016): 142-164.

10. Arrreguin-González J., et al. "Alteraciones neuropsicológicas en escolares con bajo peso al nacer (BPN) y / o muy bajo peso al nacer (MBPN) en México". Archivos de Neurociencias 22.2 (2017): 38-52.

11. Turpin H., et al. "The interplay between prematurity, maternal stress and children's intelligence quotient at age 11: A longitudinal study". Scientific Reports 9.1 (2019).

12. Sternberg R. "Intelligence". Dialogues in Clinical Neuroscience 14.1 (2012): 19-27.

13. Beláustegui CA., et al. "La familia y los programas de seguimien to". Neonatología centrada en la familia (2016).

14. Zapata KM. "Relación entre memoria de trabajo, ansiedad y rendimiento académico en estudiantes de un ISTP en el distrito de San Martín de Porres". Tesis de Maestría". Universidad Peruana Cayetano Heredia, Lima, Perú (2018). 
15. Gu H., et al. "Gradient relationship between low birth weight and IQ: A meta-analysis". Scientific Reports (2017).

16. Conde-Reyes MP., et al. "Family Functioning and Intelligence Quotient of Children Born Prematurely at 6 Years of Age". Acta Scientific Women's Health 3 (2021): 46-51.

17. Jiménez F., et al. "Padres de recién nacidos ingresados en UCIN, impacto emocional y familiar". Vox Pediátrica 11.2 (2003): 2733.

18. Fernández M., et al. "Efectos de un programa de alta precoz sobre las preocupaciones de los padres de niños prematuros". Escritos de Psicología 8.2 (2015): 43-51.

19. Mora A and Rojas AL. "Estilo de funcionamiento familiar, pautas de crianza y su relación con el desarrollo evolutivo de niños de bajo peso al nacer". Revista Latinoamericana de Ciencias Sociales, niñez y juventud 3.1 (2005): 1-25.

20. Torres JN., et al. "Atención centrada en el paciente y la familia en la unidad de cuidado intensivo pediátrica del hospital Pablo Tobón Uribe, sistematización de la experiencia”. Gerencia y Políticas de Salud 15.31 (2016): 190-201.

21. Torres MJ., et al. "Programas de seguimiento para neonatos de alto riesgo". Servicio de Neonatología. Hospital Universitario 12 de Octubre. Madrid Protocolos Diagnóstico Terapeúticos de la AEP: Neonatología 278-284.

22. Merino SE. "Calidad de vida de los cuidadores familiares que cuidan niños en situación de enfermedad crónica”. Avances en Enfermería 22.1 (2004): 39-46.

23. Dulguérian MR. "Experiencia emocional de los padres de niños nacidos prematuros y aspectos psicológicos". EMC-Pediatría 47.3 (2012): 1-6.

24. Acosta LM. "Habilidades para la crianza. Una apuesta por ser significativo para la niñez”. EN-Clave Social 5.2 (2016): 14-31.

25. Flores MM and Cortés ML. "Validación de una escala de percepción de prácticas de crianza paternas". En Flores, MM., Cortés, ML. and Morales, MT. (Eds), Estudios sobre la Crianza en México Centro Editorial Buena Nueva. Mérida, México (2017): 23-56.

26. Posada-Díaz A., et al." Crianza humanizada: Una estrategia para prevenir el maltrato infantil". Acta Pediátrica de México 29.5 (2008): 294-304.
27. Minuchin S. "Familias y terapia familiar"Gedisa. Buenos Aires (2001).

28. Montalvo J., et al. "Análisis del ciclo vital de laestructura familiar y sus principales problemas en algunas familias mexicanas". Alternativas en Psicología 17.28 (2013): 73-91.

29. Cuervo Á. "Pautas de crianza y desarrollo socioafectivo en la infancia”. Diversitas: Perspectivas en Psicología 6.1 (2010): 111-121.

30. Pons-Salvador G., et al. "Cambio y estabilidad en los factores que afectan negativamente a la parentalidad". Psicothema 17.1 (2005): 31-36.

31. Mistry R., et al. "Parenting-related stressors and self-reported mental health of mothers with young children". American Journal of Public Health 97.7 (2007): 1261-1268.

32. Torres MA. "Prácticas de crianza y educación en niños". Tesis de Maestría. CIAD, A. C. Sonora, México (2009).

33. Baumrind D. "Current patterns of parental authority". Developmental Psychology 4.1 .2 (1971): 1-103.

34. Fredrickson BL. "What good are positive emotions?" Review of General Psychology 2.3 (1998): 300-319.

35. Fredrickson BL. "The role of positive emotions in positive psychology: The broaden and build theory of positive emotions". American Psychologist 56.3 (2001): 218-226.

36. Piqueras JA., et al." Emociones negativas y su impacto en la salud mental y física". Suma Psicológica 16.2 (2009): 85-112.

37. Alvarez E., et al. "Medición de la culpa en la relación de pareja”. Prensa Médica Latinoamericana 8.2 (2014): 115-128.

38. Chóliz M. "Psicología de la Emoción". El proceso emocional Valencia (2005).

39. Palmero F., et al. "Psicología de la motivación y la emoción". McgrawHil. España (2002).

40. Calleja N. "Inventario de escalas psicosociales en México 1984-2005". Universidad Nacional Autónoma de México. México, D.F (2011).

41. Oiberman A., et al. "Entrevista Psicológica Perinatal (EPP): un instrumento en salud mental perinatal". Universidad Adventista del Plata. Centro Interdisciplinario de Investigaciones en 
Psicología Matemática y Experimental “Dr. Horacio J. A. Rimol-

di" 2 (2011): 717-730.

42. López ML. "Elaboración de una escala que mide relaciones emocionales versión para padres (ERE-P) en madres de adolescentes”. Perspectiva Metodológica 4.2 (2014): 203-224.

43. García-Méndez, M., et al. "La percepción de los padres sobre la crianza de los hijos". Acta Colombiana de Psicología 17.2 (2014): 133-141.

44. Jiménez-Quiroz R., et al. "La dinámica de Pareja ante la llegada de niños con nacimiento de alto riesgo". En Díaz-Loving R. Reyes-Lagunes I. y López Rosales F (eds.). Aportaciones Actuales a la Psicología Social IV. México: AMEPSO (2018): 2783280.

45. Jiménez R. "Experiencia sobre la crianza en padres de niños con nacimiento de alto riesgo". Tesis Maestría CENCALLI. Ciudad de México (1997).

46. Reyes-Lagunes I and García y Barragán, LF. “Procedimiento de Validación Psicométrica Culturalmente Relevante: Un ejemplo". En: Rivera S., Díaz-Loving, R., Sánchez, A., Reyes-Lagunes I. (eds.). La Psicología Social en México XII. México: AMEPSO (2008): 625-636.

47. Núñez B. “Familia y discapacidad de la Vida Cotidiana a la Teoría”. Lugar Editorial. Buenos Aires (2007).

48. López-Rubio MS. "Prácticas de Crianza y Problemas de Conducta en Preescolares: Un estudio Transcultural”. Tesis Doctoral. Universidad de Granada, España (2012).

Volume 3 Issue 7 July 2021

(C) All rights are reserved by Conde-Reyes María de la Paz., et al. 